\title{
Front Matter: Volume 6810
}

, "Front Matter: Volume 6810," Proc. SPIE 6810, Computer Image Analysis in the Study of Art, 681001 (19 March 2008); doi: 10.1117/12.792811

SPIE. Event: Electronic Imaging, 2008, San Jose, California, United States 


\title{
PROCEEDINGS Electronic Imaging \\ Sclence and Tochnology
}

\section{Computer Image Analysis in the Study of Art}

\author{
David G. Stork \\ Jim Coddington \\ Editors
}

28-29 January 2008

San Jose, California, USA

Sponsored and Published by

IS\&T-The Society for Imaging Science and Technology SPIE 
The papers included in this volume were part of the technical conference cited on the cover and title page. Papers were selected and subject to review by the editors and conference program committee. Some conference presentations may not be available for publication. The papers published in these proceedings reflect the work and thoughts of the authors and are published herein as submitted. The publishers are not responsible for the validity of the information or for any outcomes resulting from reliance thereon.

Please use the following format to cite material from this book:

Author(s), "Title of Paper," in Computer Image Analysis in the Study of Art, edited by David G. Stork, Jim Coddington, Proceedings of SPIE-IS\&T Electronic Imaging, SPIE Vol. 6810, Article CID Number (2008).

ISSN 0277-786X

ISBN 9780819469823

Copublished by

SPIE

P.O. Box 10, Bellingham, Washington $98227-0010$ USA

Telephone +1 3606763290 (Pacific Time) · Fax +1 3606471445

SPIE.org

and

IS\&T-The Society for Imaging Science and Technology

7003 Kilworth Lane, Springfield, Virginia, 22151 USA

Telephone +1 7036429090 (Eastern Time) · Fax +1 7036429094

imaging.org

Copyright (C) 2008, Society of Photo-Optical Instrumentation Engineers and The Society for Imaging Science and Technology.

Copying of material in this book for internal or personal use, or for the internal or personal use of specific clients, beyond the fair use provisions granted by the U.S. Copyright Law is authorized by the publishers subject to payment of copying fees. The Transactional Reporting Service base fee for this volume is $\$ 18.00$ per article (or portion thereof), which should be paid directly to the Copyright Clearance Center (CCC), 222 Rosewood Drive, Danvers, MA 01923. Payment may also be made electronically through CCC Online at copyright.com. Other copying for republication, resale, advertising or promotion, or any form of systematic or multiple reproduction of any material in this book is prohibited except with permission in writing from the publisher. The CCC fee code is 0277-786X/08/ $\$ 18.00$.

Printed in the United States of America.

Paper Numbering: Proceedings of SPIE follow an e-First publication model, with papers published first online and then in print and on CD-ROM. Papers are published as they are submitted and meet publication criteria. A unique, consistent, permanent citation identifier (CID) number is assigned to each article at the time of the first publication. Utilization of CIDs allows articles to be fully citable as soon they are published online, and connects the same identifier to all online, print, and electronic versions of the publication. SPIE uses a six-digit CID article numbering system in which:

- The first four digits correspond to the SPIE volume number.

- The last two digits indicate publication order within the volume using a Base 36 numbering system employing both numerals and letters. These two-number sets start with 00, 01, 02, 03, 04, 05, 06, 07, 08 , 09, OA, OB ... OZ, followed by 10-1Z, 20-2Z, etc.

The CID number appears on each page of the manuscript. The complete citation is used on the first page, and an abbreviated version on subsequent pages. Numbers in the index correspond to the last two digits of the six-digit CID number. 


\section{Contents}

$\begin{array}{ll}\vee & \text { Conference Committee } \\ \text { vii } & \text { Introduction }\end{array}$

\section{SENSING AND IMAGING}

681002 Post-capture data analysis as an aid to the interpretation of ultraviolet-induced fluorescence images [6810-02]

G. Verri, The Getty Conservation Institute (USA) and Courtauld Institute of Art (United Kingdom); D. Comelli, Politecnico di Milano (Italy); S. Cather, Courtauld Institute of Art (United Kingdom); D. Saunders, The British Museum (United Kingdom); F. Piqué, The Getty Conservation Institute (USA)

681003 Deep shadows in a shallow box [6810-03]

X. Huang, A. Mohan, J. Tumblin, Northwestern Univ. (USA)

681004 Enhancement of overwritten text in the Archimedes Palimpsest [6810-08]

K. T. Knox, Boeing LTS (USA)

\section{COLOR AND MULTISPECTRAL}

681005 Multispectral processing of combined visible and x-ray fluorescence imagery in the Archimedes palimpsest [6810-20]

D. Walvoord, A. Bright, R. L. Easton, Jr., Rochester Institute of Technology (USA)

681006 Color transplant for reverse ageing of faded artworks [6810-06]

A. Del Mastio, A. Piva, Univ. of Florence (Italy); M. Barni, Univ. of Siena (Italy); V. Cappellini, L. Stefanini, Univ. of Florence (Italy)

681007 An investigation of multispectral imaging for the mapping of pigments in paintings [6810-07]

Y. Zhao, R. S. Berns, L. A. Taplin, Rochester Institute of Technology (USA); J. Coddington, Museum of Modern Art (USA)

681008 Colour cluster analysis for pigment identification [6810-04]

K. Martinez, S. Goodall, Univ. of Southampton (United Kingdom)

681009 Image analysis of Renaissance copperplate prints [6810-09]

S. B. Hedges, Pennsylvania State Univ. (USA)

\section{STROKE AND MARK ANALYSIS}

6810 OB Drawing tool recognition by stroke ending analysis [6810-11]

M. C. Vill, R. Sablatnig, Vienna Univ. of Technology (Austria) 
$68100 \mathrm{C}$ Estimating the original drawing trace of painted strokes [6810-12]

M. Lettner, R. Sablatnig, Vienna Univ. of Technology (Austria)

6810 OD Recovering layers of brush strokes through statistical analysis of color and shape: an application to van Gogh's Self Portrait with Grey Felt Hat [6810-15]

M. Shahram, Stanford Univ. (USA); D. G. Stork, Ricoh Innovations, Inc. (USA) and Stanford Univ. (USA); D. Donoho, Stanford Univ. (USA)

TEXTURE, PATTERN, AND THREE-DIMENSIONAL ANALYSIS

6810 OF Multifractal analysis and authentication of Jackson Pollock paintings [6810-13]

J. Coddington, New York Museum of Modern Art (USA); J. Elton, Pegasus Imaging Corp.

(USA); D. Rockmore, Dartmouth College (USA); Y. Wang, Michigan State Univ. (USA)

68100 Reflections on praxis and facture in a devotional portrait diptych: a computer analysis of the mirror in Hans Memling's Virgin and Child and Maarten van Nieuwenhove [6810-16] S. Savarese, Univ. of Illinois, Urbana-Champaign (USA); R. Spronk, Queen's Univ. (Canada); D. G. Stork, Ricoh Innovations (USA) and Stanford Univ. (USA); A. DelPozo, Univ. of Illinois, Urbana-Champaign (USA)

$6810 \mathrm{OH}$ Aberration analysis of the putative projector for Lorenzo Lotto's Husband and Wife: image analysis through computer ray-tracing [6810-17]

D. Robinson, Ricoh Innovations, Inc. (USA); D. G. Stork, Ricoh Innovations, Inc. (USA) and Stanford Univ. (USA)

681001 Inferring illumination direction estimated from disparate sources in paintings: an investigation into Jan Vermeer's Girl with a Pearl Earring [6810-18]

M. K. Johnson, Dartmouth College (USA); D. G. Stork, Ricoh Innovations, Inc. (USA) and Stanford Univ. (USA); S. Biswas, Univ. of Maryland, College Park (USA); Y. Furuichi, Consultant (Japan)

$6810 \mathrm{~J}$ Image analysis of paintings by computer graphics synthesis: an investigation of the illumination in Georges de la Tour's Christ in the Carpenter's Studio [6810-19]

D. G. Stork, Ricoh Innovations, Inc. (USA) and Stanford Univ. (USA); Y. Furuichi, Consultant (Japan)

\section{INTERACTIVE PAPER SESSION}

6810 OK Global nonlinear compression of natural luminances in painted art [6810-22]

D. J. Graham, D. J. Field, Cornell Univ. (USA)

Author Index 


\title{
Conference Committee
}

\author{
Symposium Chair \\ Nitin Sampat, Rochester Institute of Technology (USA) \\ Conference Chairs
}

David G. Stork, Ricoh Innovations, Inc. (USA) and Stanford University (USA)

Jim Coddington, New York Museum of Modern Art (USA)

Program Committee

Guidomaria Cortelazzo, Università degli Studi di Padova (Italy)

Anna Bentkowska-Kafel, Courtauld Institute of Art (USA)

Peter Paul Biro, Forensic Studies in Art (Canada)

Charles R. Dyer, University of Wisconsin, Madison (USA)

Roger L. Easton, Jr., Rochester Institute of Technology (USA)

Irfan Essa, Georgia Institute of Technology (USA)

Katherine Jones-Smith, Case Western Reserve University (USA)

Christian Lahanier, Centre de Recherche et de Restauration des Musées de France (France)

Kirk Martinez, University of Southampton (United Kingdom)

Daniel N. Rockmore, Dartmouth College (USA)

Silvio Savarese, University of Illinois, Urbana-Champaign (USA)

Stefano Soatto, University of California, Los Angeles (USA)

Session Chairs

1 Invited Overview

David G. Stork, Ricoh Innovations, Inc. (USA) and Stanford University (USA)

2 Sensing and Imaging

David G. Stork, Ricoh Innovations, Inc. (USA) and Stanford University (USA)

3 Color and Multispectral

Christopher W. Tyler, Smith-Kettlewell Institute (USA)

4 Stroke and Mark Analysis

Jim Coddington, New York Museum of Modern Art (USA) 
5 Texture, Pattern, and Three-Dimensional Analysis

Jim Coddington, New York Museum of Modern Art (USA)

Downloaded From: https://www.spiedigitallibrary.org/conference-proceedings-of-spie on 26 Apr 2023 Terms of Use: https://www.spiedigitallibrary.org/terms-of-use 


\section{Introduction}

\section{From imaging to computer image analysis in the study of art}

This volume is the product of the first IS\&T-SPIE symposium to consider the widerange of computer image analysis techniques in the study of visual arts, in particular master drawings, paintings, and modern art, held January 28-29, 2008 at IS\&T-SPIE Electronic Imaging in San Jose, California. The symposium brought together leading international researchers from art museums, academia, and industry and their work demonstrated both the breadth and the power of computer techniques to shed light on problems in the understanding and interpretation of visual arts.

Science has, for many years, complemented traditional humanistic studies in the visual arts, of course, from archeology to chemical and physical analyses of paints and media to sensory and perceptual psychology of vision. Even the "dismal science" of economics has shed light on the career trajectory of artists' creativity. Closer to our interests, there is a long history of technical imaging in the study of visual arts, from x-ray imaging to infrared reflectography to UV-induced fluorescent imaging, perhaps reaching its apotheosis in the decoding of the Archimedes Palimpsest, such as discussed in this volume. Ever since the Renaissance, too, scholars and artists themselves have employed simple image analysis methods, such as the study of perspective through drawing lines over copies of artworks and making simple measurements and calculations based on the results. Throughout such work, the processed information is interpreted first and foremost by the art scholar.

We are, however, entering a new era, one in which computer algorithms themselves perform some of the analysis, analyses that simply could not be performed by even the most astute viewer because of the amount, the subtlety, or the unusual nature of the visual information. Several of the computer vision and pattern recognition algorithms scholars have applied to art were first developed in forensic image analysis, where the subtle evidence of a forger or photo manipulator escapes the scrutiny of all but the best experts from law enforcement, and in robotics and surveillance, where recognizing objects in the world and understanding their behaviors can be a matter of life and death.

Similarly to date, much image analysis has been focused on authentication problems, a small but significant part of art historical research. The insights gleaned from computer analysis are not just about authentication or for the professional art expert or collector, however. Computers can reveal the fallibility in our own perception and teach all of us to see with a more informed eye and mind. When a painting appears in perfect perspective, rigorous computer methods can reveal that it is not; when the lighting in a tableau appears to be 
from a particular location, rigorous computer methods can reveal that it is not. Armed with these new perspectives provided by computer vision, we can focus on the source of these visual discrepancies, including the artist's technical or expressive reasons for them.

There is widespread acknowledgment that problems in three important areas must be addressed if this new discipline is to advance:

- Improved communication and collaboration: It is not likely that in the near future art historians will learn sophisticated computer programming or that computer scientists will fully understand the cultural contexts in which works of art are created as deeply as do art historians; as such it is essential that there be more and improved communication between scholars in these two broad disciplines. It is only through such discussions and collaborations that computer scientists can develop and refine algorithms that will be useful addressing important art historical problems, and that art historians can learn the range of computer techniques that might be of use in their own studies. A new branch in the disciplinary tree of the "hard humanities" seems to be growing. We borrow from Albert Einstein and exaggerate a bit: Computer image analysis without deep knowledge of art is lame, art history without computer image analysis is blind.

- Unified, refined terminology: It is natural that the science of pattern classification and computer vision on the one hand, and the humanistic study of art on the other, have developed their own methodologies and terminologies. For a scientist, "focal point" refers to the position in an optical system where parallel light 1 rays are brought together; to an art historian the same term refers to the "most interesting" or most important location within a painting, where the eye is drawn. When an art historian refers to a brush stroke as "bold," or "tentative," or "free," what exactly does she mean? If these disciplines are to enhance and complement each other, scholars from each will have to learn at the very least the language and terminology of the other. When the Renaissance art scholar understands median filter and the computer scientist understands chiaroscuro, we will know we are making progress.

- Adequate data: As with any study of human activities, scientific image analysis of art is highly empirical, and thus high-quality data (images) are essential-the more the better. The computer community needs highresolution color scans of individual paintings, for instance to reveal subtle structure in brush strokes, as well as a images of a large number of different paintings, in order to learn the subtle regularities and differences between the works of different artists or between genuine and fake works. We need to find a balance between the intellectual property rights of 
museums, collectors, and copyright holders with scholars' needs for highresolution color scans of art works.

Like a microscope to a biologist, a telescope to an astronomer, a particle accelerator to a physicist, or a centrifuge to a microbiologist, these computer techniques, suitably refined, tested, and informed by art historical knowledge, will expand the power of connoisseurs, auctioneers, conservators and art historians as they address problems in the visual arts, such as authentication or understanding the working methods of artists. They will help give us all, expert and lay person alike, a deeper understanding of art.

We would like to thank our symposium program committee, Anna BentkowskaKafel, Peter Paul Biro, Guidomaria Cortelazzo, Charles R. Dyer, Roger L. Easton, Irfan Essa, Katherine Jones-Smith, Christian Lahanier, Kirk Martinez, Daniel N. Rockmore, Silvio Savarese and Stefano Soatto, for prompt, eager, and able assistance selecting papers and suggesting improvements to their authors, and our guest speaker Roger Malina, executive editor of Leonardo, for his historical insights on publishing and scholarship at the interface of science and the arts, and especially the scholars who presented their work. Finally, we express our deep gratitude to the conference organizers and leadership committees at IS\&TSPIE, particularly Michael Kriss, steering committee member, for handling several unusual challenges with wisdom and grace, making Electronic Imaging a welcoming home for this interdisciplinary research.

David G. Stork Jim Coddington 
Downloaded From: https://www.spiedigitallibrary.org/conference-proceedings-of-spie on 26 Apr 2023

Terms of Use: https://www.spiedigitallibrary.org/terms-of-use 